It is considerations of this kind which make it so difficult to forecast the distant future with that degree of assurance adopted by some people with less knowledge of the metallurgical industries.

Apart from traditional ones, there are emerging a series of spectacular uses of metals which will control the whole of the future development in many fields of engineering. It is yet to be seen how far alloys based on the newer metals can be produced with properties which have hitherto been unobtainable, and a vast, indeed unlimited, field of metallurgical endeavour is thus opened out.

The big competitor with the metals would appear to be the plasties, particularly when suitably reinforced, and in some quarters there is the assumption that these will go on getting better and cheaper, while the metals themselves are becoming increasingly scarce. It is by no means certain that this somewhat superficial view can be justified. Given sufficient energy, imagination and enthusiasm on the part of the metallurgist, the metals, by improving the methods of extraction and fabrication, can also, perhaps, become cheaper ; and new alloys of better properties will most assuredly be developed. It is Mr. Bailey's forecast that the future of the use of metals, both for the more spectacular purposes of modern engineering, and for the older, traditional ones, is not only assured but also full of interest and, in places, definitely exciting.

\section{THE IMPACT OF ENGINEERING ON SOCIETY}

$\mathrm{F}^{\mathrm{o}}$ $\mathrm{R}$ the second Graham Clark Lecture, delivered to a joint meeting of the Institution of Civil Engineers, the Institution of Mechanical Engineers and the Institution of Electrical Engineers at the Institution of Mechanical Engineers on April 27, Sir Maurice Bowra, vice-chancellor of the University of Oxford, chose to speak on "The Impact of Engineer. ing on Society", pointing out that almost every society of which we know practised engineering to some degree. A considerable degree of civilization can be secured with a minimum of engineering; but a society which does not believe in engineering, or see its possibilities, is, as the failure of the Greek and Roman systems shows, unlikely to survive. Civilization is a sensitive plant, and its first duty is to look after itself. Sir Maurice suggests that the trouble with the Ancient World was that it never had any difficulty in finding men to do tasks which we assume should be done by machines, and the educated and governing classes accordingly never turned their minds to other, and better, ways of getting work done. That the Romans, like the Chinese, rejected machines in the last resort because their ruling classes were snobs is a social fact of first importance, and Sir Maurice proceeds to demonstrate its relevance to modern times, and to show how economic forces played an important part in securing recognition of the idea that machines can do much that men cannot do by themselves and in creating opportunities for the engineer.

This great change, however, has not been revolutionary in the political sense, although it has changed the whole appearance, and even the structure, of society. Engineering is not a political activity; it aims instead at the control and exploitation of natural resources to give a greater degree of human welfare, and it becomes political only when its existence is threatened by authority or when it is taken up by authority for its own sake. Indeod, within the limits of the social frame and national States within which the engineer works, his work has a strong stabilizing influence; and so far as engineers must share the blame for man's failure to evolve means for satisfying his desire for security and prosperity, it is for sins of omission rather than of commission.

In Sir Maurice's opinion, engineers have taken too modest a view of their own task and duties. More than any other branch of human activity, engineering provides an imaginative equivalent to war and has the advantage that it creates instead of destroying. Engineering, however, contributes much towards the drive towards uniformity and the destruction of that rich variety of experience which characterizes the great humanistic tradition; and it is a serious charge that the influence of engineering interferes with the variety of the individual self and shapes it to a uniform mould by imposing on it certain patterns through modern methods of indoctrination such as the press, cinema, wireless and television. Sir Maurice questions, however, whether such means will retain their ability to impose uniformity, and he also finds grounds for hope in the undeniable tendency of men to pursue the specially difficult task of thinking for themselves.

Engineering may in the end make it easier for thought to be free, and, while admitting that engineering tends to impose a standard of culture which lacks the variety and beauty of the old craftsmanship, Sir Maurice also sees no reason why a world that relies on machines more than on handicrafts should not produce objects as satisfying as those of the old craftsmen. Because they will give delight to a far greater number of people, a new kind of grace and charm may emerge, and if men really were to know what are the ends to which he would be able to turn Nature, he should be able to do on an ever extended scale what he has already begun to do with such imagination, devotion and skill.

\section{HEALTH HAZARDS IN THE COAL AND CHEMICAL INDUSTRIES}

$T$

WE first provincial meeting of the British Occupational Hygiene Society was held in the University Hall, Liverpool, during April 19-20. In his presidential address, Dr. C. G. Warner, dust suppression scientist of the South Western Division of the National Coal Board, spoke of the satisfactory progress of the Society, an indication that by practical activities it is fulfilling its aim of promoting the science of occupational hygiene. Dr. Warner went on to talk about the remarkably changed situation regarding pneumoconiosis in coal mines which has been occasioned, on one hand, by increased aware. ness of the disease and, on the other, by measures taken for suppressing airborne dust.

South Wales was formerly a bad area, and after 1943, when the legal definition of pneumoconiosis was relaxed, the rate of certificetion rose to a peak figure of $55 \cdot 6$ men per thousand employed; by 1947 it had fallen to $30 \cdot 8$. Meanwhile, in the rest of 
Britain the corresponding figure for 1947 was only 1.9 men certified per 1,000. As knowledge of pneumoconiosis spread, the number of cases reported in other parts of Britain rose from 597 in 1945 to 3,542 in 1954. The rapid improvement in dust control had its effect, however, and the number of cases in South Wales fell from 5,224 in 1945 to 927 in 1954. Many years elapse before the disease can be detected in a coal miner, even when he is working under dusty conditions, and the present victims accumulated most of the dust load in their lungs some time ago. Such conditions are by now almost eliminated, and it is expected that in twenty years time only the mildest type of pneumoconiosis will continue to be encountered.

The first paper at the meeting was read by $H$. Pirie, of the Technical Service Department, General Chemicals Division, Imperial Chemical Industries, Ltd., his subject being the production and uses of chlorine. Chlorine was formerly transported as bleaching powder; but, since its use as a war gas in 1915, it has been transported as liquid, and many tens of thousands of tons a year are now handled in tanks, drums and cylinders. Many users, such as waterworks operators or baths superintendents, have no technical experience, and rules have been devised for their protection. The important points are as follows. (1) Liquid chlorine must be dry, and the packages and valves foolproof. Filling ratios must be observed, and containers serviced and tested regularly. (2) The eustomer should know how to use the product and to handle the packages safely. His drum and tank installations require initial inspection, and instruction and precaution cards are issued. (3) The customer should know what to do in the event of an accident. A chlorine emergency service is available to deal rapidly with trouble at the premises of any user. (4) Regular visits to the customer are made to ensure that the necessary precautions are being taken.

Trichloroethylene is one of the oldest of the commercially available organic compounds of chlorine and the one made on the largest scale. It is less dangerous than many others because it has no chronic effects. It has many uses in industry and can be used safely provided simple precautions are taken.

Mr. Pirie also referred to the system of labels for hazardous products devised by the Association of British Chemical Manufacturers. These are intended to protect the transporters of such substancesrailway employees, lorry drivers, storekeepers, etc. They are distinctive and easily recognizable, name the particular hazard, describe its nature, and give simple precautions to be observed in case of spillage, fire or other accident.

The next paper, on the technique of particle measurement in industrial hygiene, was delivered by G. L. Fairs, of the Research Department, General Chemicals Division, Imperial Chemical Industries, Ltd., who described various established methods of taking samples of dust. These included isokinetic sampling downstream of a mixing baffle, sampling in ducts, and the horizontal elutriator for size separation. Cells for sampling mists containing particles liable to change in size by evaporation or condensation were also mentioned.

Dealing with microseopic analysis of samples, Mr. Fairs stated that below 1 micron it is impossible to differentiate between the images of larger particles and diffraction haloes of much smaller ones; the electron microscope should replace the visual instru- ment for studying fine dusts. Sedimentation analysis, based on Stokes's law for the rate of fall of particles in liquid, suffers from the disadvantage that samples of the different size fractions remaining in suspension become very attenuated towards the end of the process and their removal creates a disturbance. An apparatus was described which is better in these respects, since it works by flushing out the settled particles for estimation.

Elutriation, by blowing air through a powder to carry away fine particles which settle more slowly than the air speed, enables size fractions to be determined by filtering the effluent and repeating at decreasing rates of flow. It has been found that 30 seconds of blowing is often sufficient to give adequate separation with the powder on a gauze support in a cylindrical elutriator tube.

The final paper was read by Dr. J. D. Paterson, of the Medical Department, General Chemicals Division, Imperial Chemical Industries, Ltd., and dealt with hydrofluoric acid. He said that considering only the acute effects, and ignoring the chronic, this compound must be regarded as even more severe in its action than mustard gas. In designing plant, the possibility of hydrofluoric acid coming into contact with the operators should be reduced to a minimum. In addition, to guard against mischance, adequate protective clothing is provided, means of decontamination are available, and effective medical supervision is at hand.

The acute hazard is associated with concentrations above 20 per cent, which damage body tissues; acid stronger than 60 per cent causes damage which is immediately apparent. A unique effect with hydrofluoric acid is its power of penetration to a depth where it exerts a dissolving action on cellular membranes, causing liquescent necrosis and decalcification of bone. Pain is very severe and may be immediate or delayed for some hours, according to the strength of the acid. Treatment consists of washing with copious amounts of water followed by a dressing of magnesium oxide paste. This is usually sufficient for mild burns. Injection of 10 per cent calcium gluconate into and around the burned area until there is weal formation relieves more severe cases very rapidly. Dr. Paterson has not found it necessary to give an anaesthetic before injecting. Protective clothing requires careful inspection. The majority of burns are caused by pinholes in gloves which get hard wear.

The chronic hazard is the possibility of fluorosis, which is a condition of sclerosis of bone and, in extreme cases, ossification of the ligaments. Protective clothing, including a fresh-air hood to prevent inhalation of vapour, is an insurance against fluorosis ; but when the hydrofluoric acid plant of Imperial Chemical Industries came into production, a weekly urine test and estimation of fluorine content were established. The risk of fluorosis is slight when the fluorine is below $10 \mathrm{mgm}$./ 1 . of urine, and the policy of the firm is to take $1 \mathrm{mgm}$.l. as a safe excretion-rate. It soon became apparent that the excretion-rate of fluorine was so high that daily measurements were necessary to detect peaks. After a time, these observations provided a valuable indication that all was well with the plant, and enabled small defects, which would otherwise have passed unnoticed, to be rectified. In spite of all precautions, the Medical Department still has to treat an occasional hydrofluoric acid burn, usually due to a faulty glove; but it has never had a serious case, nor a burn of the eye. Dr. Paterson also referred to chlorine and bromine trifluorides, which 
are very reactive and produce thermal burns in contact with the skin, but do not penetrate in the manner of hydrofluoric acid.

The meeting concluded with a film illustrating the work of the General Chemicals Division of Imperial Chemical Industries, Ltd., and members of the Society were conducted around the Castner-Kellner and Rocksavage Works on the following day.

\section{N. Davies}

\section{SOUTH-EASTERN UNION OF SCIENTIFIC SOCIETIES}

\section{ANNUAL CONGRESS IN TUNBRIDGE WELLS}

The

HE South-Eastern Union of Scientific Societies held its sixty-first annual congress in Tunbridge Wells during May 24-27 under the presidency of Dr. W. E. Swinton. The Tunbridge Wells Natural History Society was the host society, and the choice of Tunbridge Wells for this year's meeting was particularly appropriate since the first congress of the Union, on the occasion of its foundation sixty years ago, was held there in April 1896.

At the young naturalists' evening, a panel of experts answered questions ranging from the cause of the glowworm's glow. to the evolution of group flying, as with starlings in the autumn. Major Maxwell Knight showed his film of the hand-rearing of the cuckoo.

The Archæology Section was addressed by Major J. M. T. Burchell, his subject being the archæology of the Medway Estuary. He emphasized that geological evidence precluded the possibility of the manufacture of pottery, during Roman times, in the area and said that kilns have not been discovered. The creeks in the marshes were, during that period, used for trading purposes, and the abundance of material found, including the Upchurch ware, can probably be attributed to this source. Major Burchell afterwards conducted the party to Addington to view the work being carried out in the investigation upon a long barrow, where probing for outlying stones and digging to expose them is in progress. A visit was also made to Coldrum, an excavated long barrow, now in the care of the National Trust.

The president of the Zoology Section, Dr. H. R. Hewer, in his address spoke on the importance of keeping field records. $\mathrm{He}$ said that the natural sciences are primarily observational rather than experimental, and therefore the facilities of a laboratory and high technical training are not essential. The glory of zoology is, in the main, due to the amateur field naturalist, Darwin and Wallace being examples. The great period of accurate observational work in zoology was from 1850 to 1900, undertaken in an endeavour to determine the ancestry of species. To-day the emphasis is upon ecological studies, where natural observation with statistical correlation is of primary importance. The Zoology Section's excursion was to High Woods and Scotney Castle, by permission of Mrs. Hussey, under the leadership of Dr. L. B. Langmead.

Dr. Swinton chose as the title of his address, "Nature and the Free Mind". He began by pointing out that practical scientists at every level should be concerned with the history of science and should not leave it to the historians and philosophers. The collation and preservation of local records and the need for sharing field problems call for the national provision of finance and apparatus to help these valuable studies. Perhaps the most important role is to contribute to the understanding of the place of science in the community. While there is no need to stress some of the benefits that accrue from the advance of research, there is, at the same time, the undoubted fact that many people believe that science is something inevitable and complete, and that persistence is all that is needed to reveal the whole truth. It is salutary to remember that the rise of science was fortuitous. The ready acceptance of Darwinism may have been the result of the recog. nition of the power of scientific discovery as revealed in the Great Exhibition of 1851. Science tries to explain itself; but the symbols involved are frequently beyond the intelligibility of the public. The philosophers have maintained that, despite this, science is irrational, although that same public is now the patron of natural science. Yet, unlike religion, philosophy, manners and customs, science is nationally transferable, and the practice of its deleterious forms can be undertaken by backward people. A substantial increase in the numbers of servants, students and practitioners of technical science to enable Great Britain to compete in the world will be aided by an appreciation of the limitations of the various disciplines. The facts of science are neither good nor bad inherently, but are in accordance with their uses in human hands. Much scientific apparatus. is limited in its application by the receptive qualities of the human eye, so there are similar limits to human intelligence, perception and morality. One of the major needs in our ommunity is the realization that science is not a juggernaut come to crush its sponsors and creators, and, above all, it is still capable of being moulded into the instrument, not the master, of mankind. Despite discoveries and formulæ, there is still room for the freedom of the mind.

The address to the Botany Section was given by Prof. C. T. Ingold, speaking on "Gasteromycetes, or Nature tries again". He discussed the disparities of numbers in genera and species, saying that, while the numbers of genera of Hymenomycetes and Gasteromycetes differ sligbtly-170 in the former to 110 in the latter-there is a difference of more than ten to one in the number of species-6,900 Hymenomycetes, 630 Gasteromycetes. He suggested that, upon the evidence of spore distribution, it is probable that the Gasteromycetes have evolved from the Hymenomycetes by a process of degeneration. The members of the Section visited Saxonbury Hill and Ashdown Forest, where the rarer plants present were shown and described by Dr. Francis Rose.

The president of the Geology Section, C. C. Fagg, described the swallow holes in the Mole Gap and their effect upon the river flow and the water supply available over an area of 130 square miles with an average annual rainfall of 30 inches. The water-level is below the river bed, and the table is maintained by seepage rather than by the swallow holes, although there are twenty-nine of these still active, some being on the bare Chalk. Prof. S. W. Wooldridge, speaking on the geomorphology of the Central Weald, urged the reconsideration of the generally accepted theory of the Wealden anticline. He demonstrated that, instead of a simple anticline, there is a complex structure with at least six anticlines. Considering the effect of these upon subsequent denudation, particularly upon the direction of the flows of rivers, text-books dealing with the matter should be re- 